\title{
Bridging the Gap Between the Science and Practice of Psychology in Organizations: State of the Practice Reflections
}

\author{
Allan H. Church
}

Published online: 12 May 2011

(C) Springer Science+Business Media, LLC 2011

\begin{abstract}
This special issue of the Journal of Business and Psychology focuses on the linkage between the science and practice of psychology in applied organizational settings. The purpose of this special edition is to (a) cover current hot topics and cutting edge practice areas in HR and/or the psychology of organizations, and (b) raise compelling research issues and ideas for researchers to pursue, with an overall goal of helping bridge the science to practice gap. Each of the 14 articles included in this special issue were selected because they focus on some critical aspect of an important topic in applied organizational settings for which there is either limited, contradictory, or very little formal research in the literature. Key themes include: employee engagement, ensuring sustained behavior change through feedback and coaching, the impact of emerging technologies such as social networking sites on HR practices, and talent management and retention among others.
\end{abstract}

Keywords Scientist practitioner - HR practices .

Engagement · New technologies · Current issues ·

Industrial and organizational psychology .

Work psychology $\cdot$ Science/practice

Besides publishing refereed peer-reviewed articles, the Journal of Business and Psychology is trying to advance science and practice through unique elements such as the "Methods Corner" (e.g., Conway and Lance 2010; Tonidandel and LeBreton 2011) and on the "edge" special

\footnotetext{
A. H. Church $(\bowtie)$

PepsiCo Inc, 700 Anderson Hill Road, Purchase, NY 10577, USA

e-mail: Allan.Church@pepsico.com
}

features. The first special feature took a novel interdisciplinary look at the millennial generation (e.g., Deal et al. 2010; Twenge 2010). In this special feature, we take on an important subject that is both very exciting as well as near and dear to my heart (and the hearts of many others in the field), i.e., the linkage between the science and practice of psychology in applied organizational settings. The purpose of this special edition is to (a) cover current hot topics and cutting edge practice areas in HR and/or the psychology of organizations, and (b) raise compelling research issues and ideas for researchers to pursue, with an overall goal of helping bridge the science to practice gap.

This is an issue that has been raised frequently in the field (e.g., Cooper and Locke 2000; Hollenbeck and Smither 1998; Sackett 2007), and which some have attempted to address through other platforms including various journal formats such as the Society for Industrial-Organizational Psychology's Industrial and Organizational Psychology: Perspectives on Science and Practice journal and the Professional Practice book series. The purpose of this special issue is to take the discussion to the next level. Without taking anything away from those important efforts and outlets, the emphasis here is focused specifically on hot topics in practice, some of which do not have enough of a solid research base to warrant publication elsewhere (other than a more practitioner focused outlet), and on the associated research agenda needed to close the scientist-practitioner gap.

To this end, each of the 14 articles included in this special issue were selected because they focus on some critical aspect of an important topic in applied organizational settings for which there is either limited, contradictory, or very little formal research in the literature (some of the ideas may even be a little provocative in nature). The process for inclusion in this special issue started with an 
initial call for proposals on hot topics in the applied arena with an associated research agenda. We received submissions from both practitioners and academic colleagues. Following a review of those proposals, a number was selected for further development into full articles. The full articles were then reviewed again by the editorial team, and the final result is what you have before you.

In general, there are several common themes (and some well known topics) that run throughout the issue. There are also some innovative and emerging practice applications as well. Each of the articles contains both an overview of the practice and/or issue currently facing organizations today, as well as targeted research questions that need to be addressed. While I have no intention of commenting extensively on each of the articles uniquely (I will leave it the readers to enjoy the similarities and differences in approach, and even in some cases, on related content areas), I do want to note a few key issues and/or topics that emerged that will hopefully guide our field forward as we look to what is next in making the science to practice connection.

\section{Key Topics in the Science to Practice Gap}

The special issue opens with a highly engaging thematic story by Garman (2011) that exemplifies the very purpose of this special issue. After following the career of someone caught in the science to practice divide, he moves on to discuss several key barriers that reinforce the problem, and then provides some guidelines as to how we might bridge this gap. Although the flow of the articles is intended to be stimulating rather than clustered together by content area, as noted above, there are a number of common themes and issues that emerged:

(1) Although the topic of engagement has been the focus of attention in the business and practitioner literature for years (e.g., Church and Waclawski 2010), only recently has the discussion moved into the center stage of the academic world thanks to an article by Macey and Schneider (2008). Despite their best efforts to bring a unified theoretical approach to engagement, however, practice is both far ahead (in terms of applying various measurement models), and at the same time far behind (in terms of having a well defined construct) relative to the research literature. Given this context, it is not surprising then that four articles in this special issue address various facets of employee engagement (and related areas), and how the construct connects to other aspects of the work environment including the broader social and current economic conditions that organizations are facing. First, Van Rooy et al. (2011) review a key question facing many practitioners and business leaders today-i.e., whether engagement is still important to measure and act upon or something that can be easily ignored during a financial downturn. Later in the issue, Mone et al. (2011) address the critical role that the performance management process can play on having a highly engaged workforce. Although the next set of authors do not focus directly on engagement per se, Cardy and LengnickHall (2011) discuss the impact of having a customer orientation and equity perspective to understand retention, which is one of the potential negative outcomes of a lack of engagement on the part of the workforce. In essence, they suggest ways of turning the equation around by focusing on employees as being customers of management versus more traditional human capital frameworks. Schippers and Hogenes (2011), on the other hand, take a somewhat unique approach to the subject by focusing on the motivational facets involved and the need to better understand and measure the concept of energy in leaders (and the energy it engenders in followers) in organizational settings. The question this article poses for me is to what extent does having positive energy as an organizational leader drive engagement and enhance retention?

(2) The importance of and ability to influence individuals to change their behaviors in organizations through well-known practices and techniques. Whether via individual coaching applications (Smither 2011), or through the use of more programmatic methodologies such as 360-degree feedback (Bracken and Rose 2011), the common ground here is that research on the impact of these extensively used practices in organizations today is either mixed or virtually non-existent. Given the amount of money spent annually on these approaches in the business world, determining the real return on investment in sustained behavior change over time is a critical area for future research. How do we know if they actually make a difference?

(3) The role and validity of new technologies in applied organizational settings is addressed in three different articles, all of which point to the need for more research to understand the impact these practices may have going forward. Lesson learned here: be careful what you post on the internet. Davison et al. (2011) focus on the potential upsides and downsides to the increasing use of social networking sites (SNSs) when making a number of different HR-related decisions (e.g., recruiting, hiring, or terminating employees). Taking the discussion deeper into the specific topic of selection, Brown and Vaughn (2011) highlight the need for more focused research on the evidence of job-relevance and validity of the information obtained from SNSs to ensure that this increasingly used approach by staffing professionals and hiring managers for obtaining data on potential employees does not put organizations at future risk for potential discrimination suits or class action-related concerns. Taking the selection issue from a different perspective, Kantrowitz et al. (2011) review the application and issues related with the growing 
utilization of unproctored internet-based testing methodologies due to economic pressures, and the potential that computer adaptive testing (CAT) may have in solving for some of these. They offer a research agenda including a focus on establishing the criterion-related validity of this new approach. Taking these articles collectively, it is clear that technology and the validity of the information gleaned from the web is clearly a new frontier where research and practice need to close the connectivity gap.

The remaining articles in this issue represent other exciting and extremely relevant aspects and applications of psychology in the workplace from a number a different and interesting perspectives. Marks and Mirvis (2011) focus on the factors impacting and research still needed to ensure the success of organizational mergers and acquisitions, a practice that is as hot today as it was in the 1980s. As they note, while this area has been extensively studied in the field for decades, somehow the translation to practice-related improvements in success rates has not yet occurred. Love and Singh (2011) instead direct their attention to the hot topic of workplace banding and the potential or perceived impact that those ubiquitous "best employer" lists (e.g., which many professional and business magazines and consulting firms administer and are widely published in outlets such as Fortune and Chief Executive Magazine) can have on the attraction and retention of employees. Many organizations today are highly attuned to their external reputations (particularly on campus and with NGOs) and, as a result, spend considerable time and energy seeking out and completing these surveys so that they can receive favorable rankings. Talent management, another very hot topic in industry today (e.g., Capelli 2008; Church 2006; Effron and Ort 2010; Silzer and Dowell, 2010), also receives attention as McDonnell (2011) addresses some critical issues in this area of practice needing further research. These include the concept of identifying strategic and pivotal positions, the validity and utility of various talent identification and segmentation models, and other issues related to the application of the talent management process itself. Last but not least, Yost et al. (2011) close out this special issue by introducing a very interesting subject-i.e., HR interventions that go "viral." The focus here is on the need to understand the different factors that contribute to an organizational practice or process that is sustainable and even adaptive versus one that has only a short-lived impact (at best). Given the amount of resources both human and financial deployed against organizational change initiatives and various HR processes, this is clearly an important area for continued research.

\section{Final Comments}

Throughout my career, I have made a personal effort to try and bridge the science-practice divide myself through applied research, scholarly and practitioner-focused papers and conference sessions, and of course in the organizations with which I have worked both as an external consultant and internal practitioner. Although it is not always easy there have been some nice synergies when you can make it happen (e.g., Judge and Church 2000; Rogelberg et al. 2002).

When I was first approached about the idea for this special issue I thought what a challenge; but I also thought what a potential open field for us to engage in with audiences both academic and practice alike. Although not everyone can connect directly to both sides of the equation (e.g., some practitioners are not researched focused and some researchers do not have a real interest in translation to practice), in this special issue we have an excellent collection of articles from both practitioners and academics that focus on a number of new and hot issues in practice that need further rigorous study from the academic world. In sum, I hope that those reading this State of the Practice special issue of the Journal of Business and Psychology fully enjoy the questions and the debate, and that some ideas presented here spark many research studies and dissertations in the future.

Of course none of this could have been done without the support of many involved in this special issue. First and foremost I want to thank Steven Rogelberg, Editor of the Journal of Business and Psychology, for his support in the concept and execution (and patience) in making this special issue come to life. Next are the Editorial review team members that I enlisted to help with the initial proposal reviews and then the actual paper reviews as well. These include the following individuals:

\section{State of the Practice Editorial Review Board}

Lindsay A. Bousman, Paris Phoenix Group

Michael Bazigos, IBM Corporation

Dave Bracken, OrgVitality LLC

Peter Cairo, Oliver Wyman - Delta Executive Learning Center

Erica Desrosiers, PepsiCo Inc.

David Futrell, Eli Lilly and Company

Arlene Green, PepsiCo Inc.

Jerry Halamaj, Valtera

Ron Lawrence, VF Corporation

Alyson Margulies, PepsiCo Inc.

Jeff McHenry, Microsoft Corporation

Douglas Reynolds, Development Dimensions

International

Christopher Rotolo, PepsiCo Inc.

Lise Saari, New York University

John Scott, APTMetrics Inc. 
Rob Silzer, HR Assessment \& Development/Baruch CUNY

James Smither, La Salle University

Nancy Tippins, Valtera

I would also be remiss if I did not offer a special thank you to two of our associates at PepsiCo that truly helped me pull the pieces of the puzzle back together again for this special issue, when a memory disc failure sent the process into chaos: Timothy Lisk and Lilia Hayrapetyan. Kudos to their efforts in helping me bring this project over the finish line. Finally, my thanks to all the authors included in this issue (as well those original submitters that did not make the review stages) for their time, energy, patience, and dedication to this process. Without great content there would be no special edition.

\section{References}

Bracken, D. W. \& Rose, D. S. (2011). When does 360-feedback create behavior change? And how would we know it when it does? Journal of Business and Psychology, 26(2), 183-192.

Brown, V. R., \& Vaughn, E. D. (2011). The writing on the (Facebook) wall: The use of social networking sites in hiring decisions. Journal of Business and Psychology, 26(2), 219-225.

Capelli, P. (2008). Talent on demand: Managing talent in an age of uncertainty. Boston: Harvard Business Press.

Cardy, R. L. \& Lengnick-Hall, M. L. (2011). Will they stay or will they go? Exploring a customer-oriented approach to employee retention. Journal of Business and Psychology, 26(2), 213-217.

Church, A. H. (2006). Talent management. The Industrial-Organizational Psychologist, 44(1), 33-36.

Church, A. H., \& Waclawski, J. (2010). Organizational self-awareness and authentic engagement: The modern quest for the Holy Grail. In D. Dotlich, P. Cairo, S. Rhinesmith, \& R. Meeks (Eds.), The 2010 Pfeiffer annual: Leadership development (pp. 148-161). New York: Wiley.

Conway, J. M., \& Lance, C. E. (2010). What reviewers should expect from authors regarding common method bias in organizational research. Journal of Business and Psychology, 25, 325-334.

Cooper, C. L., \& Locke, E. A. (Eds.). (2000). Industrial and organizational psychology: Linking theory with practice. Oxford, UK: Blackwell.

Davison, H. K., Maraist, C., \& Bing, M. N. (2011). Friend of foe? The promise and pitfalls of using social networking sites for HR descisions. Journal of Business and Psychology, 26(2), 153-159.

Deal, J. J., Altman, D. G., \& Rogelberg, S. G. (2010). Millennials at work: What we know and what we need to do (if anything). Journal of Business and Psychology, 25(2), 191-199.

Effron, M., \& Ort, M. (2010). One page talent management: Eliminating complexity, adding value. Boston: Harvard Business School Publishing.

Garman, A. N. (2011). Shooting for the moon: How academicians could make management research even less irrelevant. Journal of Business and Psychology, 26(2), 129-133.
Hollenbeck, J. R., \& Smither, J. W. (1998). A letter from the editor and associate editor of Personnel Psychology. The IndustrialOrganizational Psychologist, 36(1), 107-111.

Judge, T. A., \& Church, A. H. (2000). Job satisfaction: Research and practice. In C. L. Cooper \& E. A. Locke (Eds.), Industrial and organizational psychology: Linking theory with practice (pp. 167-198). Oxford, UK: Blackwell.

Kantrowitz, T. M., Dawson, C. R., \& Fetzer, M. S. (2011). Computer adaptive testing (CAT): A faster, smarter, and more secure approach to pre-employment testing. Journal of Business and Psychology, 26(2), 227-232.

Love, L. F. \& Singh, P. (2011). Workplace branding: Leveraging human resources management practices for competitive advantage through "best employer" surveys. Journal of Business and Psychology, 26(2), 175-181.

Macey, W. H., \& Schneider, B. (2008). The meaning of employee engagement. Industrial and Organizational Psychology: Perspectives on Science and Practice, 1(1), 3-30.

Marks, M. L. \& Mirvis, P. H. (2011). Merge ahead: A research agenda to increase merger and acquisition success. Journal of Business and Psychology, 26(2), 161-168.

McDonnell, A. (2011). Still fighting the "war for talent"? Bridging the science versus practice gap. Journal of Business and Psychology, 26(2), 169-173.

Mone, E., Eisinger, C., Guggenheim, K., Price, B., \& Stine, C. (2011). Performance management at the wheel: Driving employee engagement in organizations. Journal of Business and Psychology, 26(2), 205-212.

Rogelberg, S. G., Church, A. H., Waclawski, J., \& Stanton, J. (2002). Organizational survey research. In S. G. Rogelberg (Ed.), Handbook of research methods in industrial and organizational psychology (pp. 141-160). Malden, MA: Blackwell.

Sackett, P. R. (2007). New SIOP journal: Industrial and organizational psychology: An exchange of perspectives on science and practice. The Industrial-Organizational Psychologist, 45(1), 137-138.

Schippers, M. C. \& Hogenes, R. (2011). Energy management of people in organizations: A review and research agenda. Journal of Business and Psychology, 26(2), 193-203.

Silzer, R., \& Dowell, B. E. (Eds.). (2010). Strategy-driven talent management: A leadership imperative. San Francisco: JosseyBass.

Smither, J. W. (2011). Can psychotherapy research serve as a guide for research about executive coaching? An agenda for the next decade. Journal of Business and Psychology, 26(2), 135-145.

Tonidandel, S., \& LeBreton, J. M. (2011). Relative importance analysis-A useful supplement to regression analyses. Journal of Business and Psychology, 26(1), 1-9.

Twenge, J. M. (2010). A review of the empirical evidence on generational differences in work attitudes. Journal of Business and Psychology, 25(2), 201-210.

Van Rooy, D. L., Whitman, D. S., Hart, D., \& Caleo, S. (2011) Measuring employee engagement during a financial downturn: Business imperative or nuisance? Journal of Business and Psychology, 26(2), 147-152.

Yost, P. R., McLellan, J. R., Ecker, D. L., Chang, G. C., Hereford, J. M., Roenicke, C. C., Town, J. B., \& Winberg, Y. L. (2011). HR interventions that go viral. Journal of Business and Psychology, 26(2), 233-239. 